\title{
Water extracts of Brazilian leguminous seeds as rich sources of larvicidal compounds against Aedes aegypti $\mathrm{L}$.
}

\author{
DAVI F. FARIAS ${ }^{1}$, MARIANA G. CAVALHEIRO ${ }^{1}$, MARTÔNIO P. VIANA ${ }^{2}$, \\ VANESSA A. QUEIROZ ${ }^{3}$, LADY C.B. ROCHA-BEZERRA ${ }^{1}$, ILKA M. VASCONCELOS ${ }^{1}$, \\ SELENE M. MORAIS ${ }^{3}$ and ANA F.U. CARVALHO ${ }^{2}$ \\ ${ }^{1}$ Departamento de Bioquímica e Biologia Molecular, Campus do Pici \\ Universidade Federal do Ceará, 60455-760 Fortaleza, CE, Brasil \\ ${ }^{2}$ Departamento de Biologia, Campus do Pici, Universidade Federal do Ceará, 60455-760 Fortaleza, CE, Brasil \\ ${ }^{3}$ Departamento de Química, Campus do Itaperi, Universidade Estadual do Ceará, 60740-000 Fortaleza, CE, Brasil \\ Manuscript received on May 5, 2009; accepted for publication on June 23, 2009
}

\begin{abstract}
This study assessed the toxicity of seed water extracts of 15 leguminous species upon Aedes aegypti larvae. A partial chemical and biochemical characterization of water extracts, as well as the assessment of their acute toxicity in mice, were performed. The extracts of Amburana cearensis, Anadenanthera macrocarpa, Dioclea megacarpa, Enterolobium contortisiliquum and Piptadenia moniliformis caused $100 \%$ of mortalit y after 1 to $3 \mathrm{~h}$ of exposure. They showed $\mathrm{LC}_{50}$ and $\mathrm{LC}_{90}$ values ranging from $0.43 \pm 0.01$ to $9.06 \pm 0.12 \mathrm{mg} / \mathrm{mL}$ and from $0.71 \pm 0.02$ to $13.03 \pm$ $0.15 \mathrm{mg} / \mathrm{mL}$, respectively. Among the secondary metabolite constituents, the seed water extracts showed tannins, phenols, flavones, favonols, xanthones, saponins and alkaloids. The extracts also showed high soluble proteins content ( 0.98 to $7.71 \mathrm{mg} / \mathrm{mL}$ ), lectin ( 32 to $256 \mathrm{HU} / \mathrm{mL}$ ) and trypsin inhibitory activity (3.64 \pm 0.43 to $26.19 \pm 0.05 \mathrm{gIT} / \mathrm{kg}$ of flour) The electrophoretic profiles showed a great diversity of protein bands, many of which already described as insecticide proteins. The extracts showed low toxicity to mice $\left(\mathrm{LD}_{50}>0.15 \pm 0.01 \mathrm{~g} / \mathrm{kg}\right.$ body weight), but despite these promising results, further studies are necessary to understand the toxicity of these extracts and their constituents from primary and secondary metabolism upon Ae. aegypti.
\end{abstract}

Key words: Aedes aegypti, larvicidal compounds, leguminous seeds, water extracts.

\section{INTRODUCTION}

The mosquito Aedes aegypti is the vector for the arboviruses responsible for dengue and yellow fever, both of which endemic to Central and South America, Asia and Africa (Consoli and Oliveira 1994). Contrary to yellow fever, which has been reasonably brought under control with its vaccine, dengue is still a major public health problem in many countries around the world. The only effective approach to reduce the incidence of dengue fever is by attacking the breeding places of Ae. aegypti larvae (Gluber 1989, Corbel et al. 2004), since it is more

Correspondence to: Ana Fontenele Urano Carvalho E-mail: aurano@ufc.br difficult to control the adult mosquito population (Dharmagadda et al. 2005).

This control depends basically on the use of synthetic (organochlorides, organophosphates, and carbamates) and biological insecticides (Bacillus thuringiensis spores). In Brazil, the control of Ae. aegypti populations with synthetic insecticides has turned into a serious problem. These populations have become highly resistant to these products, especially to organophosphates such as temephos (Beserra et al. 2007). Besides, most synthetic insecticides are toxic to mammals and adversely affect the environment (Dharmagadda et al. 2005). On the other hand, the biological control of 
Ae. aegypti populations with Bacillus thuringiensis is an effective alternative on combating the larval stage of the mosquito, since it is more biodegradable, nonpollutant and shows selective toxicity towards invertebrates (Polanczyk et al. 2003). Nevertheless, it is more expensive than synthetic insecticides and its effectiveness decreases in high solar incidence regions, where mosquitoes usually develop. Furthermore, studies have pointed out to the development of resistance to Bacillus spp. in Culex sp. (vector of filarial disease) (Silva and Trgis 1997, Wirth and Georghiou 1997). Considering that insects in general, and Ae. aegypti in particular, develop resistance to a variety of insecticides, this phenomenon might be demonstrated for Ae. aegypti in the near future (Hemingway and Ranson 2000, Murugan et al. 2007).

An alternative for conventional chemical and biological control is the use of natural products from plants, which have been shown to be effective insecticides and to minimize environmental impact (Fatope et al. 1993, Consoli and Oliveira 1994). In the last years, several studies have focused on plant products for controlling Ae. aegypti as larvicides and adulticides, or repellents for personal protection (Jang et al. 2002, Carvalho et al. 2003, Ramos et al. 2006, Choochote et al. 2007, Silva et al. 2008). The Leguminosae (Fabaceae) family has a wide global distribution, being well represented in Brazilian ecosystems by over 2,000 native species congregated in 188 genera. Leguminosae species are especially recognized by the nutritional value of their seeds, which are rich in proteins, carbohydrates and oil. Nevertheless, seeds do not keep only storage material. They also need physical and chemical mechanisms for protection and/or defense of the developing embryo. The compounds involved in chemical defense include lectins, protease and amylase inhibitors, toxins and low molecular mass secondary metabolites (Xavier-Filho 1993). In spite of the diversity of defense compounds, few studies have been performed with seeds, especially those from Leguminosae family concerning toxicity upon larvae of Culicidae mosquitoes. In addition, works regarding the effectiveness of seed water extracts, which are rich in primary and secondary metabolites, against Ae. aegypti larvae, are even rarer. Thus, the aim of the present study was to evaluate the larvicidal activity of water extracts of
15 leguminous seeds from the Northeast Brazil against larvae of Ae. aegypti, to characterize chemical and biochemically the active compounds, as well as to assess their acute toxicity in mice.

\section{MATERIALS AND METHODS}

\section{Plant MATERIAL}

The fresh pods (at least $500 \mathrm{~g}$ ) of each plant species (Table I) were collected in Ceará, Northeast Brazil. Plants were identified by the botanist Edson de Paula Nunes from the Universidade Federal do Ceará (UFC, Fortaleza, Brazil), and voucher specimens were deposited at Herbarium Prisco Bezerra (EAC) of the same institution.

\section{Preparation of SEed Water EXTracts}

The seeds were separated from pods and transformed into fine flour (mesh size $1.0 \mathrm{~mm}$ ) by using a blender and a coffee mill. The fine powder was placed in an oven at $45^{\circ} \mathrm{C}$ for three days to remove moisture and, then, stored in plastic bottles. The water extracts were prepared by suspending $1 \mathrm{~g}$ of seed flour into $10 \mathrm{~mL}$ of distilled water, mixing with a magnetic stirrer at $4^{\circ} \mathrm{C}$ for $4 \mathrm{~h}$. The mixture was filtered through nylon cloth and centrifuged at 20,000 x g, for $30 \mathrm{~min}$. The supernatant was used in the bioassays (larvicidal test and acute toxicity test in mice), in the quantification of soluble proteins, in the determination of protein profile and in phytochemical tests. The extracts were tested at different concentrations according to specific solubility of protein and non-protein constituents. We did not standardize the concentration to avoid extra manipulations, such as freeze-drying and other procedures, which could cause loss of the native structure of proteins and subsequent loss of activity.

\section{LARVICIDAL ACTIVITY ASSAY}

Larvae of Ae. aegypti were collected from a mosquito colony kept at NUVET/SESA (Núcleo de Controle de Endemias Transmissíveis por Vetores - Secretaria de Saúde do Estado do Ceará). Tests were run according to the methodology described by World Health Organization (WHO 2005) with some modifications. Third instar larvae of Ae. aegypti were collected with a Pasteur pipette, placed on filter paper for removal of excess water and transferred (20 per test) with a tiny brush 
TABLE I

Leguminous species (Fabaceae) employed in this study, soluble solids concentration, protein content and toxic activities of seeds water extract against Aedes aegypti larvae and mice.

\begin{tabular}{|c|c|c|c|c|}
\hline $\begin{array}{l}\text { Subfamily } \\
\text { Botanical name } \\
\text { Voucher number }\end{array}$ & $\begin{array}{l}\text { Extract soluble } \\
\text { solids } \\
(\mathrm{mg} / \mathrm{mL}) \\
\end{array}$ & $\begin{array}{l}\text { Protein } \\
\text { content } \\
(\mathrm{mg} / \mathrm{mL})\end{array}$ & $\begin{array}{l}\text { Larvicidal activity } \\
\left(\% 3^{\text {rd }} \text { larvae }\right. \\
\text { mortality })\end{array}$ & $\begin{array}{c}\text { Acute } \\
\text { toxicity } \\
\left(\mathrm{LD}_{50} \mathrm{~g} / \mathrm{kg}\right)^{1} \\
\end{array}$ \\
\hline Caesalpinoideae & & & & \\
\hline $\begin{array}{l}\text { Caesalpinia bracteosa Tul. } \\
\text { EAC } 39616\end{array}$ & $28.11 \pm 0.08$ & $2.17 \pm 0.02$ & ND & ND \\
\hline $\begin{array}{l}\text { Caesalpinia ferrea Mart. } \\
\text { EAC } 39616\end{array}$ & $28.14 \pm 0.54$ & $1.40 \pm 0.01$ & $85.04 \pm 3.84$ & ND \\
\hline $\begin{array}{l}\text { Dimorphandra gardneriana } \\
\text { EAC } 39617\end{array}$ & $26.17 \pm 0.31$ & $2.33 \pm 0.10$ & $65.08 \pm 2.56$ & ND \\
\hline $\begin{array}{l}\text { Hymenaea courbaril } \mathrm{L} . \\
\text { EAC } 38108\end{array}$ & $11.80 \pm 0.10$ & $1.13 \pm 0.07$ & $13.33 \pm 0.54$ & ND \\
\hline $\begin{array}{l}\text { Senna obtusifolia (L.) H.S. Irwin \& Barneby } \\
\text { EAC } 39320\end{array}$ & $25.22 \pm 0.95$ & $1.47 \pm 0.02$ & $41.67 \pm 1.97$ & ND \\
\hline $\begin{array}{l}\text { Senna rugosa (L.) H.S. Irwin \& Barneby } \\
\text { EAC } 38112\end{array}$ & $54.71 \pm 2.02$ & $2.40 \pm 0.11$ & $16.67 \pm 0.78$ & ND \\
\hline $\begin{array}{l}\text { Faboideae } \\
\text { Amburana cearensis (Fr. Allem.) A.C.Sm. } \\
\text { EAC } 39618\end{array}$ & $24.75 \pm 1.31$ & $0.98 \pm 0.01$ & $100.0 \pm 0.0$ & ND \\
\hline $\begin{array}{l}\text { Dioclea megacarpa } \text { Rolfe } \\
\text { EAC } 38110\end{array}$ & $26.33 \pm 1.09$ & $7.46 \pm 0.73$ & $100.0 \pm 0.0$ & $0.77 \pm 0.04$ \\
\hline $\begin{array}{l}\text { Erythrina velutina Willd } \\
\text { EAC } 35979\end{array}$ & $32.25 \pm 1.37$ & $7.71 \pm 0.66$ & $75.12 \pm 1.89$ & $1.00 \pm 0.01$ \\
\hline $\begin{array}{l}\text { Lonchocarpus sericeus (Poiret) Kunth } \\
\text { EAC } 39615\end{array}$ & $33.29 \pm 1.22$ & $7.70 \pm 0.81$ & $70.09 \pm 2.34$ & ND \\
\hline $\begin{array}{l}\text { Mimosoideae } \\
\text { Anadenanthera macrocarpa (Benth.) Brenan } \\
\text { EAC } 38697\end{array}$ & $42.64 \pm 2.45$ & $1.56 \pm 0.21$ & $100.0 \pm 0.0$ & $0.15 \pm 0.008$ \\
\hline $\begin{array}{l}\text { Enterolobium contortisiliquum (Vell.) Morong } \\
\text { EAC } 38115\end{array}$ & $35.23 \pm 1.54$ & $3.13 \pm 0.15$ & $100.0 \pm 0.0$ & $1.1 \pm 0.01$ \\
\hline $\begin{array}{l}\text { Parkia platycephala Benth. } \\
\text { EAC } 38109\end{array}$ & $28.50 \pm 0.82$ & $1.32 \pm 0.08$ & $7.89 \pm 0.27$ & ND \\
\hline $\begin{array}{l}\text { Piptadenia moniliformis Benth. } \\
\text { EAC } 35974\end{array}$ & $36.70 \pm 1.36$ & $4.30 \pm 0.21$ & $100.0 \pm 0.0$ & ND \\
\hline $\begin{array}{l}\text { Plathymenia reticulata Benth. } \\
\text { EAC } 38114\end{array}$ & $22.31 \pm 0.75$ & $1.22 \pm 0.06$ & $81.67 \pm 3.29$ & ND \\
\hline Distilled water & - & - & ND & ND \\
\hline
\end{tabular}

into 150 -mL disposable plastic cups containing $100 \mathrm{~mL}$ of water extract of each seed. Larval mortality/survival was monitored during the first three hours of exposure and registered after $24 \mathrm{~h}$ at room temperature $\left(25^{\circ} \mathrm{C}\right)$. For each extract, three independent experiments were run in triplicate and distilled water was used as negative control. Larvae were considered dead when no movement could be detected after they had been touched with a tiny brush. The results were expressed as mean \pm standard deviation of per cent mortality for all experiments. The water extracts that showed $100 \%$ of larval mortality were diluted and evaluated again to determine the lethal concentration for $50 \%$ and $90 \%$ of larvae $\left(\mathrm{LC}_{50}\right.$ and $\mathrm{LC}_{90}$, respectively).

\section{Assay for Acute ToXicity IN Mice}

Acute toxicity in mice ( $n=6)$ was verified by intraperitonial injection ( $30 \mathrm{~mL} / \mathrm{Kg}$ body weight) of diluted and crude water extract of each seed according to Vasconcelos et al. (1994). This procedure was approved by the 
Animal Experimentation Ethics Committee of Universidade Federal do Ceará (CEPA), Protocol No. 34/09, which adopts the guidelines of Colégio Brasileiro de Experimentação Animal (COBEA).

\section{Characterization of SeEd Water Extracts}

\section{Soluble protein content}

The total soluble protein content was determined by the colorimetric method of Coomassie Brilliant Blue according to Bradford (1976).

\section{Content of some bioactive proteins}

Lectin activity was assessed by serial two-fold dilution of samples (Moreira and Perrone 1977). The water extracts were diluted with $0.15 \mathrm{M} \mathrm{NaCl}$ and mixed with erythrocytes from rabbit blood $(20 \mathrm{mg} / \mathrm{mL}$ suspension prepared in $0.15 \mathrm{M} \mathrm{NaCl}$ ) treated with proteases from Aspergillus oryzae (EC 232-642-4, Sigma-Aldrich Co. USA), in a concentration of $1 \mathrm{mg} / \mathrm{mL}$. The degree of agglutination was visually monitored after the tubes had been left to stand at $37^{\circ} \mathrm{C}$ for $30 \mathrm{~min}$, and at room temperature $\left(22 \pm 3^{\circ} \mathrm{C}\right)$ for an additional $30 \mathrm{~min}$. The results are reported as hemagglutination title (HU), which is the reciprocal of the highest dilution giving visible agglutination. Trypsin inhibitory activity was determined by a slight modification of the method originally described by Kakade et al. (1969), using trypsin enzyme and LBAPNA as substrate. Activity was expressed as the amount of trypsin inhibited, calculated from a calibration curve using soybean trypsin inhibitor.

\section{Electrophoresis}

Sodium dodecyl sulphate-polyacrylamide gel electrophoresis (SDS-PAGE) was performed according to the method of Laemmli (1970). SDS-PAGE was carried out in a 2 -mm vertical slab gel $(10 \times 8 \mathrm{~cm})$ containing stacking gel mix, 5\% total acrylamide, and main running gel mix, $17.5 \%$ acrylamide, prepared in $3.0 \mathrm{M}$ Tris-HCl, $\mathrm{pH} 8.8$. Samples ( $20 \mu \mathrm{l}$ of each water extract) were dissolved in Tris-HCl 0.0625 M, pH 6.8, containing $1 \%$ SDS and $1 \% \beta$-mercaptoethanol $(1: 1, \mathrm{v} / \mathrm{v})$ and incubated at $100^{\circ} \mathrm{C}$ for $10 \mathrm{~min}$. Treated samples containing approximately $50 \mu \mathrm{g}$ of protein content were inoculated in wells, and electrophoresis was carried out at $20 \mathrm{~mA}$ constant current for $2 \mathrm{~h}$. Bands were visualized by staining with $0.05 \%$ Coomassie Brilliant Blue R-250. Molecular mass markers employed were phosphorilase B (97.4 KDa), bovine serum albumin (66.2 $\mathrm{KDa})$, ovalbumine $(45.0 \mathrm{KDa})$, carbonic anhydrase $(31.0 \mathrm{KDa})$, soybean trypsin inhibitor $(20.1 \mathrm{KDa})$ and lysozyme (14.2 KDa) (AMRESCO Inc., Ohio, USA).

\section{Phytochemical Study of Seed Water Extracts}

Phytochemical tests to detect the presence of secondary metabolites as phenols, tannins, leucoantocianidins, flavonoids, esteroids, triterpens, and alkaloids were performed according to Matos (1988). These tests are based on visual observation of color modification or precipitates formation after the addition of specific reagents.

\section{Statistical Analysis}

Mortality data were subjected to probit analysis (Finney 1971) to estimate lethal concentration that kills $50 \%$ and $90 \%$ of $A$ e. aegypti larvae $\left(\mathrm{LC}_{50}\right.$ and $\mathrm{LC}_{90}$, respectively).

\section{RESULTS AND DISCUSSION}

Many studies have described the larvicidal activity against Ae. aegypti of extracts from leaves, stems, and roots of leguminous species prepared with organic solvents (Pohlit et al. 2004, Luna et al. 2005, Mendonça et al. 2005, Omena et al. 2007). Nevertheless, little attention has been addressed to the potential of seeds as sources of secondary compounds with larvicidal properties (Jang et al. 2002, Luna et al. 2005). Much scarcer are the studies that use water extracts for obtaining primary compounds admittedly toxic to Ae. aegypti larvae (Carlini et al. 1997).

The results of the water extract toxicity assays against larvae of Ae. aegypti (Table I) showed that, among fifteen extracts, only four have larval mortality rates lower than $50 \%$. The other extracts caused larval mortality rates over $60 \%$, being noteworthy the water extracts activity of Amburana cearensis, Dioclea megacarpa, Anadenanthera macrocarpa, Enterolobium contortisiliquum and Piptadenia moniliformis, which caused $100 \%$ of mortality after 1 to $3 \mathrm{~h}$ of exposure. Luna et al. (2005) did not detect Ae. aegypti larval mortality in ethanolic extract of A. macrocarpa wood bark. These 
authors have described only $5 \%$ of larval mortality after the exposure to ethanolic extract of Dioclea virgata leaves, which is much smaller than that shown for $D$. megacarpa seed water extract (100\%) observed in the present work. In spite of the water extracts present high concentrations of total soluble solids $(>20 \mathrm{mg} / \mathrm{mL})$, it seems that these are not directly associated with the mortality rate. One extract (Senna rugosa) with a concentration above $40 \mathrm{mg} / \mathrm{mL}$ showed a relatively low larval mortality rate, whereas other extracts with half this concentration caused $100 \%$ of mortality after a short exposure time.

Can these promising results be attributed only to secondary metabolites present in the extracts? According to Table II, among secondary metabolites, the seed water extracts of these five plant species contain mainly tannins, phenols, flavones, favonols, xanthones, saponins and alkaloids. These secondary compounds were similar to those shown by Luna et al. (2005) in leaves, roots and wood bark alcoholic extracts of several plant species. Specifically, the leguminous species studied by Luna et al. (2005) with strong larvicidal activity were shown to contain flavones, phenols and alkaloids, the same compounds detected in the present work. Besides, the role of phenol compounds, such as thymol (an alkyl-derivative of phenol) and tannins as larvicidal compounds against $A e$. aegypti, is well known (Carvalho et al. 2003, Silva et al. 2004). However, it is evident that these compounds are also present in the water extracts of species with the lowest activities, Senna rugosa and S. obtusifolia. Thus, it is questionable whether this could be explained only by the low levels of these larvicidal compounds in the less active extracts, or whether other compounds, such as proteins with insecticide activity, are present in the extracts. It is possible that proteins with insecticidal activity such as lectins, toxins, arcelins and protease inhibitors (Carlini and Grossi-de-Sá 2002, Whetstone and Hammock 2007) may be present in the water extracts, considering the extraction conditions and the common occurrence of these compounds in species of the Leguminosae family (Vasconcelos and Oliveira 2004). Thus, it is likely that these compounds contribute for larvicidal activity of the five most potent seed extracts aforementioned.

The soluble protein contents (Table I) ranged from
4 to $28 \%$ of total soluble solids. Ramos et al. (2006) have detected high mortality rates of Ae. aegypti larvae working with fractions of Calotropis procera latex, which are rich in cysteinic proteases $(5.2 \mathrm{mg} / \mathrm{mL})$. Recently, Sá et al. (2008) showed the first report of larvicidal activity against Ae. aegypti of a plant purified protein, the lectins from Myracrodruon urundeuva. It has been reported that lectins and toxins possess insecticidal activity against Diptera, but little is known about the toxic activity of serine and cysteine protease inhibitors, alfa-amylase inhibitors and arcelins, in spite of the reported action of these compounds against other insect orders (Carlini and Grossi-de-Sá 2002). The five most potent plant species described in the present work contain potentially active proteins against insects (Table III). Lectin activity was detected in the seed water extracts from D. megacarpa $(256 \mathrm{HU} / \mathrm{mL})$ and E. contortisiliqüum (32 HU/mL). Besides, all the studied seed water extracts showed trypsin inhibitory activity, ranging from $3.64 \pm 0.43$ to $26.19 \pm 0.05 \mathrm{~g}$ of inhibited trypsin per $\mathrm{kg}$ of flour. Some compounds responsible for these activities in the water extracts were previously purified. The $A$. cearensis and $E$. contortisiliqüum seeds possess trypsin inhibitors with molecular mass of $13.6 \mathrm{KDa}$ (Tanaka et al. 1989) and 23.0 KDa (Oliva et al. 1987), respectively. D. megacarpa seeds possess a three subunits lectin with molecular masses of 25-26, 13-14, and 8-9 KDa (Moreira et al. 1983). Recently, a chitin-binding vicilin from E. contortisiliqüum seeds was purified and shown to be toxic against bean bruchid pests (Callosobruchus maculatus and Zabrotes subfasciatus) (Moura et al. 2007). These protein compounds could be observed in the electrophoretic profiles of the water extracts (Fig. 1). Therefore, it is reasonable to consider that the proteins naturally involved in plant defense can contribute somehow to the larvicidal activity of the seeds water extract.

The $\mathrm{LC}_{50}$ and $\mathrm{LC}_{90}$ values of the most active seed water extracts (A. macrocarpa, A. cearensis, D. megacarpa, E. contortisiliquum, and $P$. moniliformis) against Ae. aegypti larvae (Table IV) ranged from $0.43 \pm 0.01$ to $9.06 \pm 0.12 \mathrm{mg} / \mathrm{mL}$ and from $0.71 \pm 0.02$ to 13.03 $\pm 0.15 \mathrm{mg} / \mathrm{mL}$, respectively. The A. macrocarpa water extract was the most powerful with $\mathrm{LC}_{50}$ of 0.43 $\pm 0.01 \mathrm{mg} / \mathrm{mL}$ and $\mathrm{LC}_{90}$ of $0.71 \pm 0.02 \mathrm{mg} / \mathrm{mL}$. These values are much higher than those detected in samples 
DAVI F. FARIAS et al.

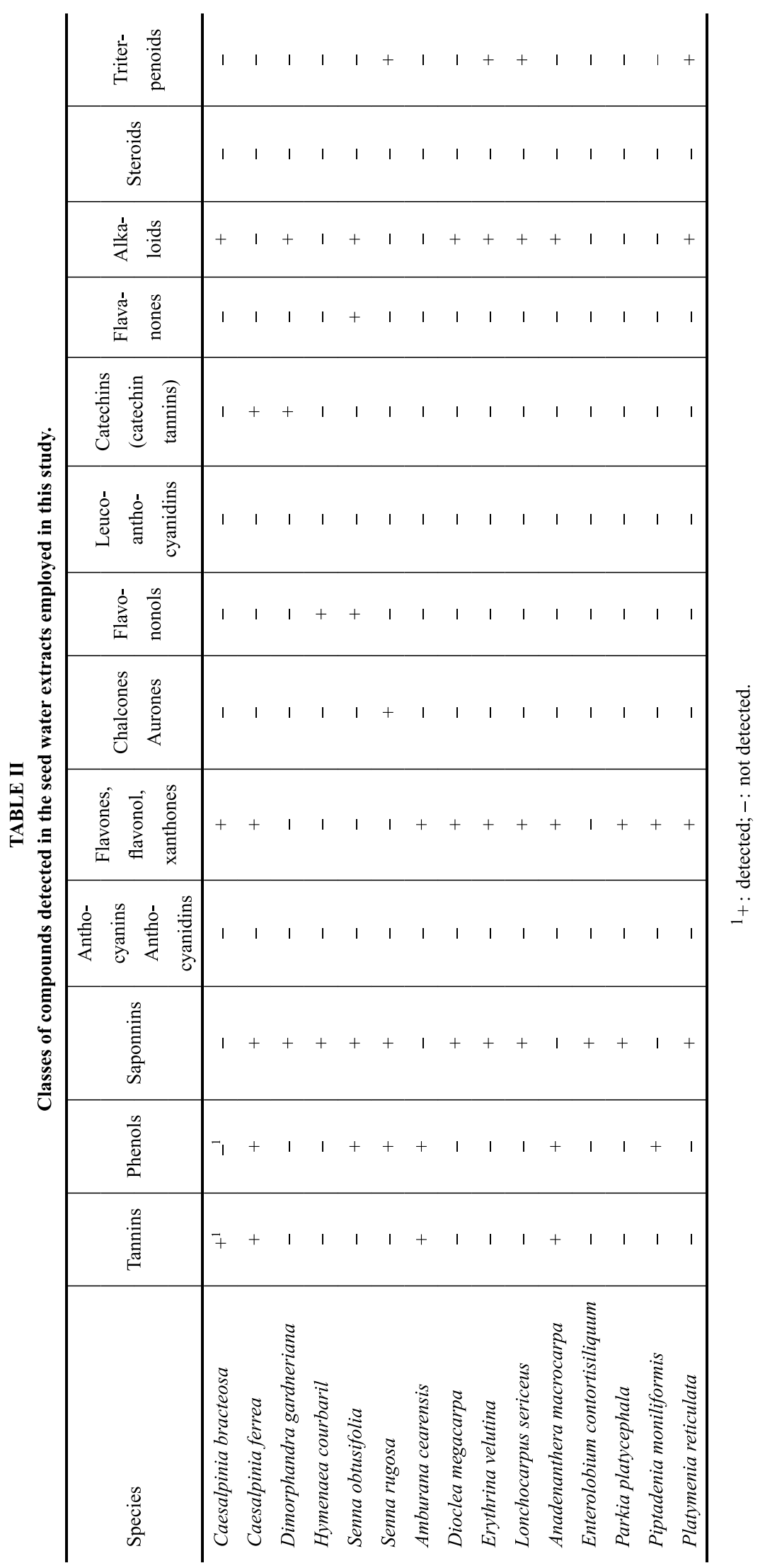




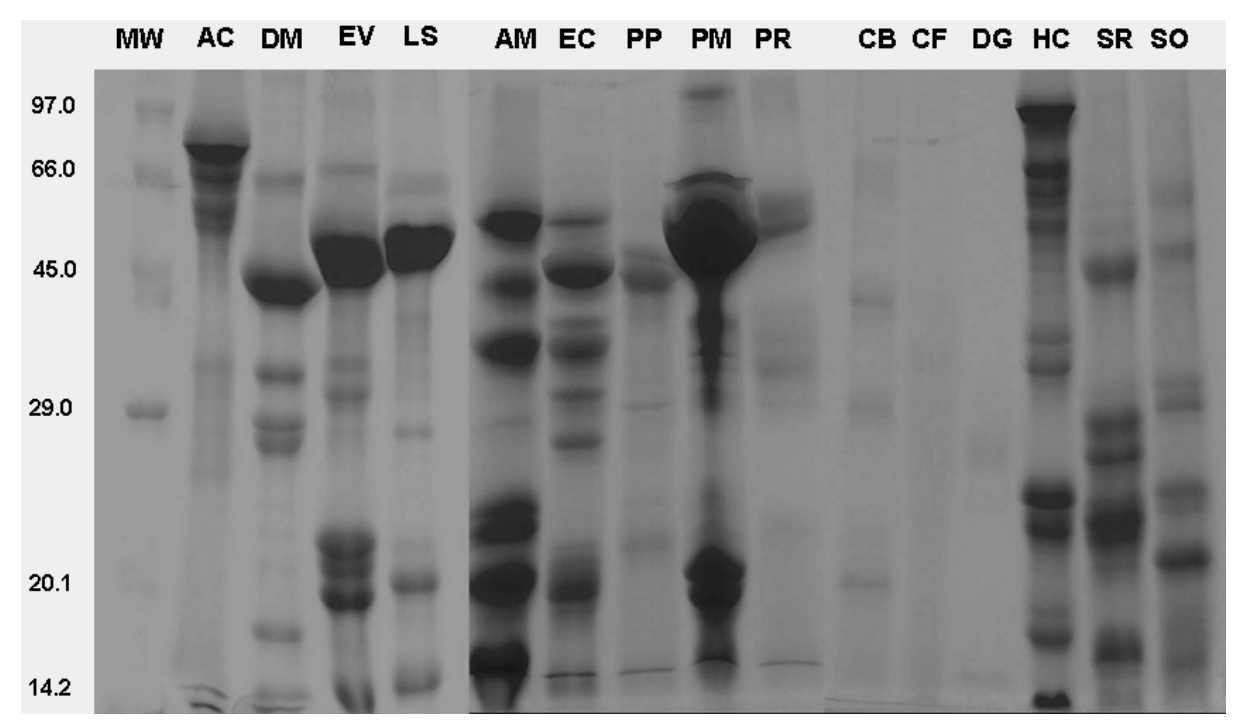

Fig. 1 - Electrophoresis of water extract proteins of Amburana cearensis (AC), Dioclea megacarpa (DM), Erythrina velutina (EV), Lonchocarpus sericeus (LS), Anadenanthera macrocarpa (AM), Enterolobium contortisiliquum (EC), Parkia platycephala (PP), Piptadenia moniliformis (PM), Plathymenia reticulata (PR), Caesalpinia bracteosa (CB), Caesalpinia ferrea (CF), Dimorphandra gardneriana (DG), Hymenaea courbaril (HC), Senna rugosa (SR), Senna obtusifolia (SO). A total of $50 \mu \mathrm{g}$ of protein was applied in the gel.

TABLE III

Content of some bioactive proteins (lectins and trypsin inhibitors) in leguminous seed water extracts with larvicidal activity against $3^{\text {rd }}$ instars of Aedes aegypti.

\begin{tabular}{l|c|c}
\hline Species & $\begin{array}{c}\text { Lectin } \\
\text { activity }\end{array}$ & $\begin{array}{c}\text { Trypsin } \\
\text { inhibitor } \\
\text { activity }\end{array}$ \\
\hline Faboideae & $\mathrm{ND}$ & $12.23 \pm 0.29$ \\
Amburana cearensis & 256 & $10.78 \pm 0.10$ \\
Dioclea megacarpa & $\mathrm{ND}$ & $3.64 \pm 0.43$ \\
Mimosoideae & 32 & $26.19 \pm 0.05$ \\
Anadenanthera macrocarpa & $\mathrm{ND}$ & $8.85 \pm 0.47$ \\
Pipterolobium contortisiliquum &
\end{tabular}

${ }^{1}$ Lectin activity is expressed as hemagglutination unit (HU) per $\mathrm{mL}$ of water extract. One HU represents the reciprocal of the highest dilution giving visible agglutination of the treated rabbit erythrocytes with protease solution $(1 \mathrm{mg} / \mathrm{mL} ; 1: 100, \mathrm{v} / \mathrm{v}) .{ }^{2}$ Trypsin inhibitory activity is expressed as g of trypsin inhibited per $\mathrm{kg}$ of flour. ND = Not Detected. The values are mean \pm standard deviation $(n=3)$.

obtained from more selective extractions with apolar solvents such as ethanol, methanol etc. Jang et al. (2002), working with methanolic extracts of leguminous seeds, showed approximately $50 \%$ of Ae. aegypti larvae mortality at the concentration of $0.04 \mathrm{mg} / \mathrm{mL}$. However, the $\mathrm{LC}_{50}$ value of $A$. macrocarpa water extract is much lower than that found by Sá et al. (2008) for bark and heartwood crude water extracts of Myracrodruon urundeuva $\left(\mathrm{LC}_{50} 8.81\right.$ and $14.86 \mathrm{mg} / \mathrm{mL}$, respectively). The lectins purified from these extracts showed low values of $\mathrm{LC}_{50}, 0.125 \mathrm{mg} / \mathrm{mL}$ for bark lectin, and $0.04 \mathrm{mg} / \mathrm{mL}$ for heartwood lectin (Sá et al. 2008). Thus, if the compound responsible for the larvicidal activity in the most promising water extracts is of protein nature, its activity during the purification process will tend to increase, being comparable to extracts rich in secondary compounds.

All these considerations may provide evidences that seeds may be promising sources of larvicidal compounds, and that water may be an efficient solvent to extract bioactive substances.

Among all evaluated water extracts (15), only four of them (A. macrocarpa, D. megacarpa, E. contortisiliquum and E. velutina) presented acute toxicity on mice (Table I). The extract of the species $A$. macrocarpa showed the highest toxicity with a $\mathrm{LD}_{50}$ of $0.15 \mathrm{~g} / \mathrm{kg}$ body weight, a value considered as slightly toxic according to Hodge and Sterner's criteria (1949), and as 
TABLE IV

$\mathrm{LC}_{50}$ and $\mathrm{LC}_{90}$ of water extracts of leguminous seeds against $3^{\text {rd }}$ instars of Aedes aegypti after $24 \mathrm{~h}$ of exposure ${ }^{1}$.

\begin{tabular}{l|c|c}
\hline Species & $\begin{array}{c}\mathrm{LC}_{50} \\
(\mathrm{mg} / \mathrm{mL})\end{array}$ & $\begin{array}{c}\mathrm{LC}_{90} \\
(\mathrm{mg} / \mathrm{mL})\end{array}$ \\
\hline Faboideae & & \\
Amburana cearensis & $8.10 \pm 0.27$ & $11.67 \pm 0.32$ \\
Dioclea megacarpa & $6.68 \pm 0.11$ & $9.75 \pm 0.17$ \\
\hline Mimosoideae & & \\
Anadenanthera macrocarpa & $0.43 \pm 0.01$ & $0.71 \pm 0.02$ \\
Enterolobium contortisiliquum & $2.39 \pm 0.03$ & $3.79 \pm 0.05$ \\
Piptadenia monoliformis & $9.06 \pm 0.12$ & $13.03 \pm 0.15$ \\
\hline
\end{tabular}

${ }^{1} \mathrm{LC}_{50}$ and $\mathrm{LC}_{90}$ are the lethal concentrations $(\mathrm{mg} / \mathrm{mL})$ at which $50 \%$ and $90 \%$ of the larvae showed mortality, respectively. Values are means \pm standard deviation $(n=3)$.

toxic by WHO's criteria (1994). On the other hand, the extract of the other most active species, A. cearensis, D. megacarpa, E. contortisiliquum and P. moniliformis, were considered slightly toxic (Hodge and Sterner criteria) and noxious (WHO criteria). Thus, it seems that there is a trend of these bioactive compounds to show higher toxicity towards invertebrates and be safe to mammals.

In conclusion, leguminous seeds are promising sources of primary metabolites, especially proteins, and secondary metabolites with larvicidal activity against Ae. aegypti with low toxicity to mammals. Nevertheless, further studies must be dedicated to understand the high toxicity of the seed extracts upon larvae of $A e$. aegypti and to identify the compounds from primary and secondary metabolism involved in the toxicity.

\section{ACKNOWLEDGMENTS}

The authors wish to thank Ministério da Saúde, through Departamento de Ciência e Tecnologia (DECIT), Secretaria de Ciência, Tecnologia e Insumos Estratégicos (SCTIE), Conselho Nacional de Desenvolvimento Científico e Tecnológico (CNPq) and Fundação de Amparo à Pesquisa do Estado do Ceará (FUNCAP) for their financial support.

\section{RESUMO}

Este trabalho objetivou avaliar a toxicidade dos extratos aquosos de sementes de 15 espécies de leguminosas contra larvas de Aedes aegypti. Foi realizada uma caracterização química e bioquímica parcial dos extratos aquosos e a avaliação da toxicidade aguda em camundongos. Os extratos de Amburana cearensis, Anadenanthera macrocarpa, Dioclea megacarpa, Enterolobium contortisiliquum e Piptadenia moniliformis causaram $100 \%$ de mortalidade depois de 1 a $3 \mathrm{~h}$ de exposição e mostraram valores de $\mathrm{CL}_{50}$ e $\mathrm{CL}_{90}$ entre $0,43 \pm 0,01$ e 9,06 \pm 0,12 e entre $0,71 \pm 0,02$ e $13,03 \pm 0,15 \mathrm{mg} / \mathrm{mL}$, respectivamente. Dentre os constituintes do metabolismo secundário, os extratos das sementes apresentaram taninos, fenóis, flavonas, flavonóis, xantonas, saponinas e alcalóides. Os extratos apresentaram alto teor de proteínas solúveis $(0,98$ to $7,71 \mathrm{mg} / \mathrm{mL})$, lectina (32 to $256 \mathrm{UH} / \mathrm{mL}$ ) e inibidor de tripsina $(3,64 \pm 0,43$ to $26,19 \pm 0,05 \mathrm{gIT} / \mathrm{kg}$ de farinha). O perfil eletroforético mostrou uma grande diversidade de proteínas, muitas das quais já descritas como inseticidas. Os extratos mostraram baixa toxicidade ao camundongo $\left(\mathrm{DL}_{50}>0,15 \pm 0,01 \mathrm{~g} / \mathrm{kg}\right.$ peso corporal), porém apesar desses resultados promissores, estudos posteriores são necessários para compreender a toxicidade desses extratos e de seus constituintes do metabolismo primário e secundário sobre Ae. aegypti.

Palavras-chave: Aedes aegypti, compostos larvicidas, sementes de leguminosas, extratos aquosos.

\section{REFERENCES}

Beserra EB, Fernandes CRM, Queiroga MFC AND CASTRO-JR FP. 2007. Resistência de populações de $A e$ des aegypti (L.) (Diptera: Culicidae) ao organofosforado temefós na Paraíba. Neotrop Entomol 36: 303-307.

BRADFORD MM. 1976. A rapid and sensitive method for the quantification of microgram quantities of protein utilizing principle of protein-dye binding. Anal Biochem 72: 248254.

CARlini CR AND Grossi-De-SÁ MF. 2002. Plant toxic proteins with insecticidal properties. A review on their potentialities as bioinsecticides. Toxicon 20: 1519-1539.

Carlini CR, Oliveira AE, Azambuja P, Xavier-FiLHO J AND WELLS MA. 1997. Biological effects of canatoxin in different insect models: evidence for a proteolytic activation of the toxin by insect cathepsin-like enzymes. J Econ Entomol 90: 340-348.

Carvalho AFU, Melo VMM, Craveiro AA, MachaDo MIL, BANTIM MB AND RABElo EF. 2003. Larvicidal activity of the essential oil from Lippia sidoides Cham. against Aedes aegypti Linn. Mem Inst Oswaldo Cruz 98: 569-571. 
Choochote W, Chaithong U, Kamsuk K, Jitpakdi A, Tippawangkosol P, Tuetun B, Champakaew D AND PitASAWAT B. 2007. Repellent activity of selected essential oils against Aedes aegypti. Fitoterapia 78: 359364.

Consoli RA And Oliveira RL. 1994. Principais Mosquitos de Importância Sanitária no Brasil. Fiocruz, Rio de Janeiro.

Corbel V, Duchon S, ZAim M AND Hougard JM. 2004. Dinotefuran: a potential neonicotinoid insecticide against resistant mosquitoes. J Med Entomol 41: 712-717.

Dharmagadda VSS, Naik SN, Mittal PK AND VASUDEVAN P. 2005. Larvicidal activity of Tagetes patula essential oil against three mosquito species. Biores Technol 96: $1235-1240$.

FATOPe MO, Ibrahim H AND TAKedA Y. 1993. Screening of higher plants reputed as pesticides using the brine shrimp lethality assay. Pharm Biol 31: 250-254.

FINNEY DJ. 1971. Probit Analysis. Cambridge University Press, Cambridge.

Gluber D. 1989. Aedes aegypti and Aedes aegypti-borne disease control in the 1990's: top down or bottom up. Am J Trop Med Hyg 40: 571-578.

HEMINGWAY J AND RANSON H. 2000. Insecticide resistance in insect vectors of human disease. Annu Rev Entomol 45: 371-391.

Hodge HC AND STERnER JH. 1949. Tabulation of toxicity classes. Am Ind Hyg Assoc Quart 10: 93-98.

JANG YS, KIM MK, AHN YJ AND LEE HS. 2002. Larvicidal activity of leguminous seeds and grains against Aedes aegypti and Culex pipiens pallens. J Am Mosq Control Assoc 18: 210-213.

KAKAde ML, Simon N ANd Liener IE. 1969. An evaluation of natural vs synthetic substract for measuring the antitryptic of soybean samples. Cereal Chem 46: 518526.

LAEMMLI UK. 1970. Cleavage of structural proteins during the assembly of the head of bacteriophage T4. Nature 227: 680-685.

Luna JS, Santos AF, Lima MRF, Omena MC, MenDONÇA FAC, BIEBER LW AND SANT'ANA AEG. 2005. A study of the larvicidal and molluscicidal activities of some medicinal plants from northeast Brazil. J Ethnopharmacol 97: 199-206.

MATOS FJA. 1988. Introdução à Fitoquímica Experimental. Edições UFC, Fortaleza.

MEndonça FAC, Silva KFS, SAntos KK, RibeiroJUNIOR KAL AND SANT'ANA AEG. 2005. Activities of some Brazilian plants against larvae of the mosquito Aedes aegypti. Fitoterapia 76: 629-636.

Mendonça FAC, Silva KFS, SAntos KK, RibeiroJUNIOR KAL AND SANT'ANA AEG. 2005. Activities of some Brazilian plants against larvae of the mosquito Aedes aegypti. Fitoterapia 76: 629-636.

Moreira RA And Perrone JC. 1977. Purification and partial characterization of a lectin from Phaseolus vulgaris. Plant Physiol 59: 783-787.

Moreira RA, BArros ACH, StewArt JC AND PUSZTAI A. 1983. Isolation and characterization of a lectin from the seeds of Dioclea grandiflora (Mart). Planta 158: 6369.

Moura Ft, Oliveira AS, Macedo Ll, Vianna AL, Andrade LB, Martins-Miranda AS, Oliveira JT, SAntos EA AND SALES MP. 2007. Effects of a chitin-binding vicilin from Enterolobium contortisiliquum seeds on bean bruchid pests (Callosobruchus maculatus and Zabrotes subfasciatus) and phytopathogenic fungi (Fusarium solani and Colletrichum lindemuntianum). J Agric Food Chem 55: 260-266.

Murugan K, Murugan P And Noortheen A. 2007. Larvicidal and repellent potential of Albizzia amara Boivin and Ocimun basilicum Linn against dengue vector, Aedes aegypti (Insecta: Diptera: Culicidae). Biores Technol 98: 198-201.

Oliva ML, SAmpaio UM And SAmpaio CA. 1987. Serine- and SH-proteinase inhibitors from Enterolobium contortisiliquum beans. Purification and preliminary characterization. Braz J Med Biol Res 20: 767-70.

Omena MC, NaVArRo DMAF, Paula JE, Luna JS, LIMA MRF AND SANT'ANA AEG. 2007. Larvicidal activities against Aedes aegypti of some Brazilian medicinal plants. Biores Technol 98: 2549-2556.

Pohlit AM ET AL. 2004. Screening of plants found in the State of Amazonas, Brazil for larvicial activity against Aedes aegypti larvae. Acta Amazônica 34: 97-105.

Polanczyk RA, Garcia MO And Alves SB. 2003. Potencial de Bacillus thuringiensis israelensis Berliner no controle de Aedes aegypti. Rev Saúde Pública 37: 813816.

Ramos MV, BANDEIRA GP, Freitas CDT, NOGUEIRA NAP, AlEnCAR NMN, Sousa PAS AND CARVAlHo AFU. 2006. Latex constituents from Calotropis procera (R. Br.) display toxicity upon egg hatching and larvae of Aedes aegypti (Linn.). Mem Inst Oswaldo Cruz 101: 503-510. 
SÁ RA, Santos NDL, Silva CSB, Napoleão TH, Gomes FS, CaVada BS, Coelho LCBB, NaVArro DMAF, BIEBER LW AND PAIVA PMG. 2008. Larvicidal activity of lectins from Myracrodruon urundeuva on Aedes aegypti. Comp Biochem Physiol Part C: Toxicol Pharmacol 149: 300-306.

Silva MH AND TRGRIS L. 1997. Reversal of low level resistance to Bacillus sphaericus in field population of the southern house mosquito (Diptera: Culicidae) from an urban area. J Ecol Entomol 90: 229-303.

Silva HHG, Silva IG, Santos RMG, Filho ER AND ELIAS CN. 2004. Larvicidal activity of tannins isolated of Magonia pubescens St. Hil. (Sapindaceae) against Aedes aegypti (Diptera, Culicidae). Rev Soc Bras Med Trop 37: 396-399.

Silva WJ, DóRia GAA, MaIA RT, Nunes RS, CARVALho GA, Blank AF, Alves PB, MarÇal RM And CAVAlCANTI SCH. 2008. Effects of essential oils on Aedes aegypti larvae: Alternatives to environmentally safe insecticides. Biores Technol 99: 3251-3255.

Tanaka AS, Sampaio MU, Sampaio CA and Oliva ML. 1989. Purification and preliminary characterization of Torresea cearensis trypsin inhibitor. Braz J Med Biol Res 22: 1069-71.

VAsconcelos IM And Oliveira JTA. 2004. Antinutritional properties of plants lectins. Toxicon 44: 385-403.
VAsconcelos IM, Trentin A, Guimarães JA AND CARLINI CR. 1994. Purification and hysicochemical characterization of soyatoxin, a novel toxic protein isolated from soyabeans (Glycine max). Arch Biochem Biophys 312: 357-366.

Whetstone PA And Hammock BD. 2007. Delivery methods for peptide and protein toxins in insect control. Toxicon 49: 576-59.

Wirth MC AND Georghiou GP. 1997. Cross-resistance among Cry IV toxins of Bacillus thuringiensis subsp. israelensis in Culex quinquefasciatus (Diptera: Culicidae). J Ecol 90: 1471-1477.

World Health Organization (WHO). 1994. International Programme on Chemical Safety - IPCS. Assessing humam health risks of chemical: derivation of guidance values for health - based exposure limits. World Health Organization, Geneva.

World Health Organization (WHO). 2005. Guidelines for laboratory and field testing of mosquito larvicides. WHO/CDS/WHOPES/GCDPP/2005.13.

XAVIER-Filho J. 1993. Sementes e suas defesas contra insetos. Projeto multinacional de biotecnologia e alimentos. Organização dos Estados Americanos. Edições UFC, Fortaleza. 